\title{
Языковой портфель как один из способов формирования преемственности между школой и вузом
}

\author{
Губченко Л.В., \\ учитель английского языка \\ МОУ Гимназии №2, г. Нерюнгри \\ E-mail: sh04@nerungri.edu.ru
}

Использование языкового портфеля (ЯП) при обучении иностранным языкам получает всё большее распространение. Это связано со стремлением соответствовать единым европейским стандартам в образовании. Роль ЯП в школьном образовательном процессе очень велика. Создание портфолио - это инновационная технология обучения ИЯ, которая способствует развитию рефлексии и самооценки учащихся, демонстрирует достижения и как следствие развивает мотивацию, совершенствует иноязычную коммуникативную компетенцию учащихся.

В нашей работе мы рассматривали языковой портфель как технологию, которая получает все большее распространение в процессе изучения иностранного языка.

В работе проанализированы несколько типов портфолио, которые значительно различаются не только по своим целям, но и по способам работы, их создании и т.д. Классификация портфолио выполняется также и по предметам. В нашей работе мы рассмотрели четыре типа портфолио

Первый тип портфолио - это “папка достижений”, направленная на повышение собственной значимости ученика и отражающая его успехи (похвальные грамоты за учебу).

Второй тип - рефлексивное портфолио, помогающий отследить результативность его деятельности как в количественном, так и качественном плане. В эту папку собираются сочинения, изложения, эссе, рисунки. Второй тип портфолио подразумевает под собой собрание работ школьника в той или иной предметной области.

Третий тип портфолио - проблемно-исследовательский, связанный с написанием реферата, исследовательской работы и т.

Четвертый тип портфолио - тематический, создаваемый в процессе изучения какой-либо большой темы, раздела.

Более подробно в работе проанализированы типы языкового портфолио, которые также отличаются по целям и способам работы с ними.

- ЯП как инструмент самооценки достижений учащегося в процессе овладения ИЯ и уровня владения изучаемым языком Это так называемая “папка достижений”(Self-Assessment Language Portfolio).

- ЯП как инструмент автономного изучения ИЯ (Language Learning Portfolio).Этот тип ЯП содержит материалы, которые представляют для учащегося определенные рекомендации по самостоятельной работе над различными аспектами изучаемого языка

- ЯП как инструмент демонстрации учебного продукта — результата овладения ИЯ (Administrative Language Portfolio). Этот тип ЯП содержит, как правило, образцы лучших самостоятельных работ учащегося, выполненных в течение определенного периода. В эту папку собираются все контрольные и творческие работы ученика: сочинения, изложения, эссе, рисунки, поделки, зачетные работы,презентации). 
- ЯП как инструмент обратной связи в учебном процессе по иностранному языку (Show Case, Feedback Language Portfolio). Языковой портфель типа Feedback включает в себя материалы выполненных учебных заданий, которые фиксируют степень сформированности различных компетенций иноязычного речевого общения.

- ЯП типа Show Case - выполняет репрезентативную функцию: накапливать и представлять образцы речевых произведений, опыта иноязычного речевого общения, использования изучаемого языка в различных ситуациях, а также самостоятельные, в том числе и творческие работы учащегося

- Многоцелевой ЯП, отражающий различные цели в области овладения ИЯ (Comprehensive Language Portfolio).

Как любая технология языковой портфель имеет свою структуру и обычно состоит из трех разделов:

1. Языковой nacnopm - обзор индивидуальных компетенций в языке/-ах в данный период времени.

2. Языковая биография - способствует развитию навыков планирования, рефлексии и самооценки в процессе изучения языка. Развитие полиязычности, компетенции в ряде языков.

3. Досье - материалы для документирования и иллюстрирования достижений или опыта, описанных в паспорте и языковой биографии

Основными принципами технологии работы с ЯП являются:

1. Самооценка результатов

2. Систематичность и регулярность самомониторинга.

3. Самостоятельность мышления.

4. Структуризация материалов портфеля, логичность и лаконичность всех письменных пояснений

5. Целостность, тематическая завершенность представленных в портфеле материалов.

6. Аккуратное и эстетичное оформление портфеля.

7. Наглядность и обоснованность презентации портфеля ученика.

Формы работы с языковым портфелем в практике преподавания ИЯ могут быть различными в зависимости от поставленной цели. Языковой портфель- гибкое учебное средство, которое может быть адаптировано практически к любой учебной ситуации, различающейся по цели обучения, возрасту обучаемых, уровня овладения иностранными языками, условиям обучения, индивидуальным особенностям учащихся.

Большой интерес представляет практическая часть работы, где описываются способы, использованные при написании работы, а также представлено подробное описание электронного приложения, разработанного в виде сайта и размещенного в интернет

Основными разделами сайта являются:

1. Тематический словарь

2. Грамматика

3. Топики

4. Пословицы и поговорки

В разработке находятся разделы:

1. Тесты

2. Отзывы и пожелания

Выводы: 
Языковой портфель, таким образом, является своего рода «зеркалом» процесса изучения иностранного языка. В нем посредством рефлексивной самооценки учащихся отражаются основные компоненты этого процесса, что способствует созданию условий для развития их учебной компетенции и автономии. Создание языкового портфеля - на сегодняшний день необходимое условие успешного изучения иностранного языка. Работа над созданием языкового портфеля повышает мотивацию учащегося к изучению языка. Языковой портфель позволяет вывести на новый уровень самостоятельную работу учащихся.

\section{Список литературы:}

1. Беркалиев Т.Н., Заир-Бек Е.С., Тряпицына А.П. Инновации и качество школьного образования. Каро, СПб, 2007.

2. Кудрявцева Е.Ю. Использование языкового портфеля в изучении немецкого языка как второго иностранного. // Иностранные языки в школе. - 2007. - № 7 (22).

3. Лабазина Л.Н. Европейский языковой портфель - средство оценки и самооценки знаний учащихся оп ино странным языкам. // Ярославский педагогический вестник. 2003. - № 2 (35).

4. Поляков О.Г. Самоконтроль в обучении английскому языку. // Иностранные языки в школе. - 2005. - №7 (48).

5. Соколова Л.А. Рефлексивный компонент деятельности как необходимое условие развития учителя и учащихся. // Иностранные языки в школе. - 2005. - № 1 (19).

6. Сороковых Г.В., Шумова И.В. Методический портфель студента-практиканта как способ формирования профессиональной компетентности будущего учителя иностранных языков. // Иностранные языки в школе. - 2007. - № 1 (54).

7. Тамбовкина Т.Ю. Самообучение иностранному языку как основная составляющая языкового самообразования. // Иностранные языки в школе. - 2005. - № 5 (76).

8. http://www.native-english.ru/grammar

9. http://studyfun.ru/

10.http://www.homeenglish.ru/Proverbs8.htm

11. http://iloveenglish.ru/topics 12. ru.wix.com

Фонетические средства выражения эмотивности в художественном тексте (на примере разносистемных языков)

Зотова Н.В., соискатель, Технический институт (филиал) Северо-Восточного федерального университета, 2. Нерюнгри

E-mail: tyurikalova@mail.ru

Научный руководитель: д.филол.н., доцент Кондратьева Н.В.

Живая речь обладает способностью ярче выражать эмоции нежели ее письменный аналог. Однако, считать письменную речь менее эмотивной 